\section{Training Systems for Cold Climate Interspecific Hybrid Grape Cultivars in Northern Climate Regions}

\author{
Madeline Wimmer ${ }^{1}$, Beth Ann Workmaster, and Amaya Atucha ${ }^{2}$
}

AdDitionAl INDEX wORDs. cold hardy, Vitis riparia, 'Marquette', 'Frontenac', 'Brianna', 'La Crescent'

Summary. Training systems influence grapevine (Vitis sp.) size, shape, and canopy architecture, which ultimately affects yield and fruit composition. Cold climate interspecific hybrid grapes (CCIHG) have propelled the creation of a new and fastgrowing grape and wine industry in the northeast and upper midwest of the United States. This study evaluated the effect of three training systems: high cordon (HC), midwire vertical shoot positioning (VSP), and modified Scott Henry (SH) on vine growth, yield, and fruit composition of four CCIHG cultivars, Brianna, Frontenac, La Crescent, and Marquette, during two growing seasons. The divided canopy training system $\mathrm{SH}$ increased the crop yield per meter of row in all cultivars relative to HC and VSP, despite reduction in crop size imposed by crop thinning in vines trained to SH. VSP-trained vines had lower yields compared with $\mathrm{HC}$, and this was most evident during the second year of the study, as vines were still being trained when the study commenced. Despite the higher crop size associated with vines trained in a SH system, there were minimal differences in fruit soluble solid concentration (SSC), titratable acidity (TA), and $\mathrm{pH}$ at harvest time. No differences were observed in vine size, expressed as dormant cane pruning weights, among training systems possibly because of the control of vegetative vigor, especially in VSP-trained vines, through shoot positioning and summer pruning. CCIHG cultivars appear to have the capacity to support higher yields under SH and HC systems without compromising fruit quality; however, labor requirements involved in establishing and maintaining more complex training systems should be considered when selecting a training system for CCIHG cultivars.

$\mathrm{T}$ raining systems can determine a vineyard's production potential, as grapevine form defines the spatial distribution of leaves and shoots within a canopy, affecting sunlight interception and thus photosynthesis capacity of leaves (Katerji et al., 1994; Reynolds and Vanden Heuvel, 2009; Schultz, 1995; Smart et al., 1990). The percent of photosynthetically active radiation $(P A R)$ absorbed by each grape leaf is related

Department of Horticulture, University of WisconsinMadison, 1575 Linden Drive, Madison, WI 53706

This work is supported by Specialty Crop Research Initiative (grant no. 2011-51181-30850/project accession no. 0225755) from the U.S. Department of Agriculture, National Institute of Food and Agriculture (NIFA)

We thank Janet Hedtcke and Rebecca Harbut for their work in the design and establishment of the West Madison Agricultural research Station (WMARS) vineyards and oversight of data collection. Also, we thank all the WMARS staff and University of Wisconsin-Madison undergraduate interns and graduate students who assisted in the daily and seasonal tasks of vineyard management and data collection.

${ }^{1}$ Current address: Grape and Wine Institute, University of Missouri-Columbia, 108 Eckles, Columbia, MO 65211 .

${ }^{2}$ Corresponding author. E-mail: atucha@wisc.edu.

https://doi.org/10.21273/HORTTECH03946-17 to the depth of its position within the canopy, where inner canopy leaves may intercept as little as $1 \%$ solar radiation, by contrast to the $80 \%$ to $90 \%$ absorbed by outer leaves (Dokoozlian and Kliewer, 1995). Variations in training can increase the amount of exposed canopy surface, as well as the interception of diffuse light inside the canopy, thereby increasing leaf photosynthetic efficiency (Smart et al., 1982a). Adequate light exposure to buds during their development is critical for flower bud initiation (Vasconcelos et al., 2009), affecting node fertility and fruitfulness (Dry, 2000; Sánchez and Dokoozlian, 2005), which ultimately can lead to differences in yield (Smart et al., 1982a, 1982b). Increased sunlight penetration in a canopy modifies temperate experiences of leaves and clusters, a factor particularly important in cold climates, enhancing the concentrations of sugars, anthocyanins, and total phenolics, whereas lowering organic acid concentrations of fruit (Pereira et al., 2006; Smart and Robinson, 1991).

Training systems can influence vine size and vegetative vigor (Reynolds and Vanden Heuvel, 2009), which can be an effective tool when growing vigorous cultivars, such as hybrid and American (Vitis labrusca) cultivars, in cool climates with fertile soils, like those found in midwestern and eastern United States (Bordelon et al., 2008; Howell et al., 1987, 1991). Single canopy with VSP (single bilateral low- or midcordon system with upward shoot positioning) is the standard training system used for European wine grape (Vitis vinifera) cultivars, as it provides an adequate vine balance and fruit quality; however, in hybrids grapes, this system can increase vegetative vigor and limit sunlight interception in the fruit zone (Bavougian et al., 2012; Reynolds and Wardle, 1994; Zoecklein et al., 2008). By contrast, divided canopy training systems support a greater number of shoots per length of trellis than single canopy systems and can reduce vegetative

\begin{tabular}{llll}
\hline $\begin{array}{l}\text { Units } \\
\begin{array}{l}\text { To convert U.S. to SI, } \\
\text { multiply by }\end{array}\end{array}$ & U.S. unit & SI unit & $\begin{array}{l}\text { To convert SI to U.S., } \\
\text { multiply by }\end{array}$ \\
\hline 10 & $\%$ & $\mathrm{~g} \cdot \mathrm{kg}^{-1}$ & 0.1 \\
10 & $\%$ & $\mathrm{~g} \cdot \mathrm{L}^{-1}$ & 0.1 \\
0.4047 & $\mathrm{acre}(\mathrm{s})$ & $\mathrm{ha}$ & 2.4711 \\
100 & $\mathrm{bar}$ & $\mathrm{kPa}$ & 0.01 \\
29.5735 & $\mathrm{fl} \mathrm{oz}$ & $\mathrm{mL}$ & 0.0338 \\
0.3048 & $\mathrm{ft}$ & $\mathrm{m}$ & 3.2808 \\
3.7854 & gal & $\mathrm{L}$ & 0.2642 \\
2.54 & inch $(\mathrm{es})$ & $\mathrm{cm}$ & 0.3937 \\
25.4 & inch $(\mathrm{es})$ & $\mathrm{mm}$ & 0.0394 \\
0.4536 & $\mathrm{lb}$ & $\mathrm{kg}$ & 2.2046 \\
1.1209 & $\mathrm{lb} / \mathrm{acre}$ & $\mathrm{kg} \cdot \mathrm{ha}^{-1}$ & 0.8922 \\
1.4882 & $\mathrm{lb} / \mathrm{ft}$ & $\mathrm{kg} \cdot \mathrm{m}^{-1}$ & 0.6720 \\
28.3495 & $\mathrm{oz}$ & $\mathrm{g}$ & 0.0353 \\
1 & $\mathrm{ppm}$ & $\mathrm{mg} \cdot \mathrm{kg}^{-1}$ & 1 \\
$\left({ }^{\circ} \mathrm{F}-32\right) \div 1.8$ & ${ }^{\circ} \mathrm{F}$ & ${ }^{\circ} \mathrm{C}$ & $\left({ }^{\circ} \mathrm{C} \times 1.8\right)+32$ \\
& & & \\
\hline
\end{tabular}


vigor and increase yields of hybrid cultivars (Reynolds et al., 1995, 2004), thus reducing the need for summer pruning to control vine growth and increase sunlight penetration in the fruit zone.

CCIHG cultivars have propelled the expansion of the grape and wine industries to northern temperate climates because of their ability to survive midwinter temperatures as cold as $-35{ }^{\circ} \mathrm{C}$ (Hemstad and Luby, 2000). However, high vegetative vigor, inconsistent yields, and low fruit quality are some of the main challenges faced by the industry (Atucha et al., 2018). Appropriate management practices of CCIHG have proven to differ from those for European wine grape cultivars, but there is limited information on best management practices to improve yield and fruit composition of these new cultivars. The objective of this study was to evaluate the effects of three training systems: VSP, HC (single bilateral HC system with downward shoot positioning), and a modified SH \{double bilateral system with a low-cordon with downward shoot positioning [lower $\mathrm{SH}$ cordon (SHL)] and a midcordon with upward shoot positioning [upper $\mathrm{SH}$ cordon (SHU)] , on vine growth, yield, and fruit composition of four CCIHG cultivars: Brianna, Frontenac, La Crescent, and Marquette.

\section{Materials and methods}

Site DEscription AND PLANT MATERIAL. The trial was established in 2012 at the West Madison Agricultural research Station (WMARS), located in Verona, WI (lat. $43^{\circ} 03^{\prime} 37$ $" \mathrm{~N}$, long. $89^{\circ} 31^{\prime} 54^{\prime \prime} \mathrm{W}$ ) in U.S. Department of Agriculture Plant Hardiness Zone 5a (U.S. Department of Agriculture, 2012). The vineyard soil is well-drained Griswold loam (U.S. Department of Agriculture, 2017). Soil samples taken at vineyard establishment reported a soil $\mathrm{pH}$ of 7.1 (1:1 soil to water), organic matter was $3 \mathrm{~g} \cdot \mathrm{kg}^{-1}$ soil, and phosphorus and potassium concentrations were 64 and $127 \mathrm{mg} \cdot \mathrm{kg}^{-1}$ soil (Bray I), respectively. The 30-year (1981-2010) mean ambient temperature, frost-free days, and precipitation at WMARS are $6.5{ }^{\circ} \mathrm{C}$, $157 \mathrm{~d}$, and $903 \mathrm{~mm}$, respectively (National Oceanographic and Atmospheric Administration, 2017). Cumulative precipitation (millimeters) and growing degree days, calculated using a base temperature of $10^{\circ} \mathrm{C}$ and a daily maximum temperature threshold of $30{ }^{\circ} \mathrm{C}$, from 1 Apr. until 31 Oct. in both years are presented in Fig. 1.

One-year-old bare root vines of four CCIHG cultivars, Brianna, Frontenac, La Crescent, and Marquette, were purchased from a commercial nursery (Northeastern Vine Supply, West Pawlet, VT) and planted in 2012. Vines were trained to three systems: VSP, HC, and a modified
SH. VSP and HC cordons were trained to aboveground distances of 3.5 and $6 \mathrm{ft}$, respectively. The $\mathrm{SH}$ system was modified from that system's original design by establishing a vertically divided double curtain from spurs maintained on two sets of cordons with the SHU at $4 \mathrm{ft}$ and the SHL at $3.5 \mathrm{ft}$ aboveground. Shoots from the SHU were trained to upward positions, whereas those from SHL were trained to downward positions. Rows were oriented north-south with

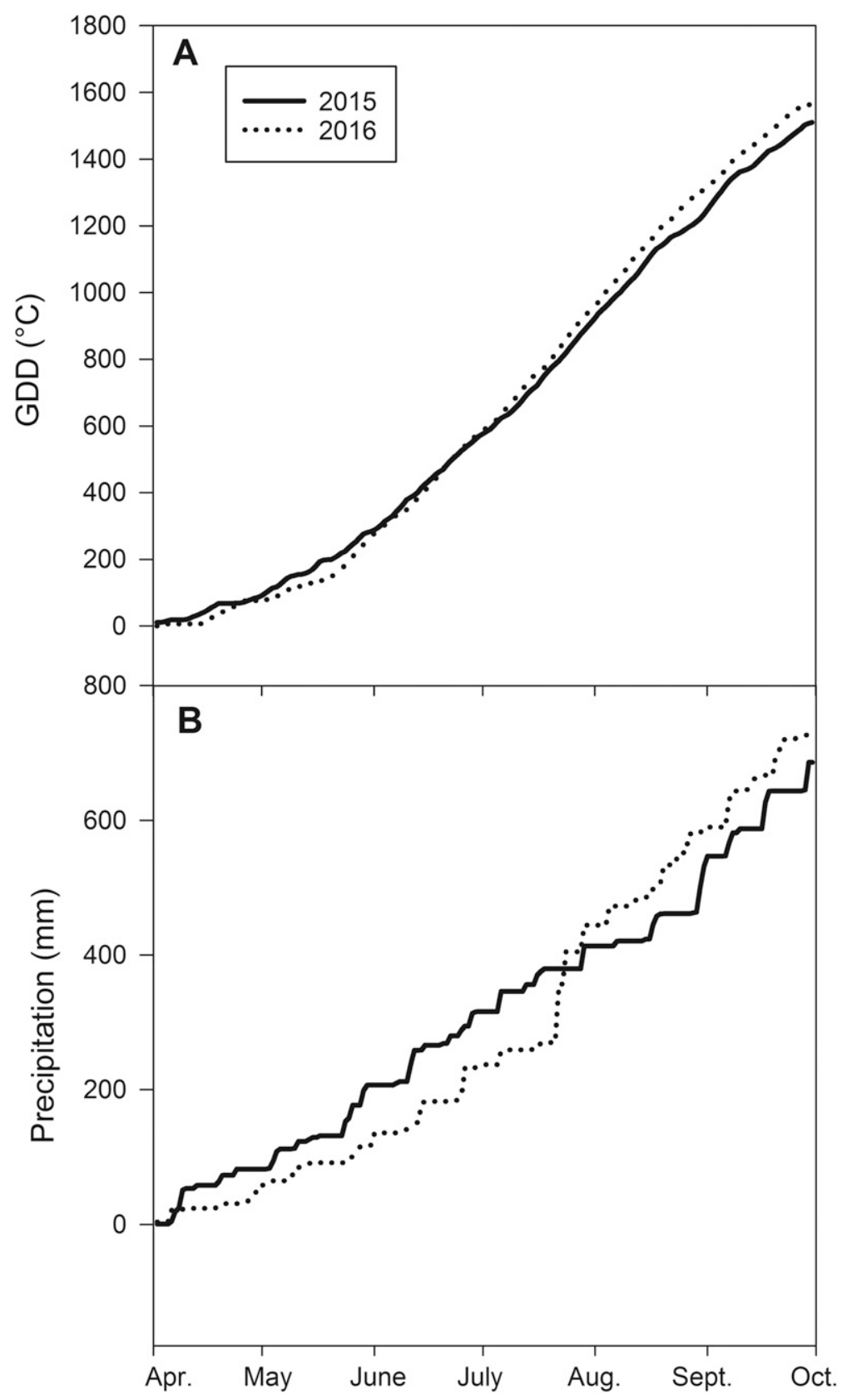

Fig. 1. Summary of weather conditions at West Madison Agricultural Research Station, Verona, WI during 1 Apr. through 30 Sept. in 2015 and 2016. (A) Cumulative growing degree days [GDD (base $\left.\left.10^{\circ} \mathrm{C}\right)\right]$ and $(\mathrm{B})$ monthly precipitation totals: $\left(1.8 \times{ }^{\circ} \mathrm{C}\right)+32={ }^{\circ} \mathrm{F}, 1 \mathrm{~mm}=0.0394$ inch. 
$10 \mathrm{ft}$ between rows and $6 \mathrm{ft}$ between vines, for a total density of 583 vines/ acre. The trial was established as a randomized complete block design, consisting of four blocks with 12 panels of four vines, for a total of 48 panels. Each treatment panel consisted of four vines of a single cultivar trained to one system.

Commercial vineyard practices were implemented for cultural management of grapes (Bordelon et al., 2015; Dami et al., 2005; Wolf, 2008). Permanent sod alleys of $2 \mathrm{~m}$ were maintained between rows and mowed on a regular schedule. Woodchip mulch was applied every other year on a $1-m$ strip within the planting row that was maintained weed-free with postemergence herbicide. Drip irrigation was installed at the time of planting and consisted of one drip line per row with emitters spaced every 18 inches capable of providing $\mathrm{l}$ gal/h. Irrigation frequency was determined by tensiometer (model SR; Irrometer Co., Riverside, CA) installed at 10-inch depth, and vines were irrigated when soil tension reached 35-40 $\mathrm{kPa}$. The vineyard was irrigated throughout the first year when vines were planted but only used as needed during subsequent years. All vines were trained with double trunks during establishment and spur pruned yearly to two nodes per spur in the VSP and SH systems and to four nodes per spur in the HC system.

The total shoot count was standardized among training systems via shoot thinning to a density of 20 shoots $/ \mathrm{m}$ of cordon when shoots were 10 to $20-\mathrm{cm}$ long. Bird netting was installed 2-3 weeks postveraison. Disease and insect pests were monitored through the entire season and controlled based on standard commercial practices (Bordelon et al., 2015). Vines were sprayed with foliar magnesium sulfate ( $5 \mathrm{lb} /$ acre) during July 2015 and 2016. Nitrogen, in the form of urea, was applied in Aug. 2015 (40 lb/acre urea). Canopies trained as VSP were hedged twice to $3.5 \mathrm{ft}$ long. SHU shoots were hedged once to $3.2 \mathrm{ft}$. Both HC and SHL were skirted once to 5.6 and $2 \mathrm{ft}$, respectively, during each season. Vines in VSP system were particularly vigorous and required additional leaf and lateral shoot removal during the growing season to allow sunlight penetration into the fruit zone. During veraison, two to three basal leaves and lateral shoots in the first three node positions were removed to increase sunlight penetration.

Fruit YIELD. During 2015 and 2016 , crop size was reduced by $25 \%$ in $\mathrm{SH}$ by thinning one cluster from every other shoot to prevent overcropping the young vines. Vines were harvested as a single event from each cultivar based on fruit quality parameters, and all vines in the panel were harvested. 'Brianna', 'Frontenac', 'La Crescent', and 'Marquette' clusters were harvested at (respectively) $19 \%$, $23 \%, 20 \%$, and $24.5 \%$ SSC in 2015 ; $17 \%, 22 \%, 19 \%$, and $23 \%$ SSC in 2016 ; and $6,12,13$, and $10.5 \mathrm{~g} \cdot \mathrm{L}^{-1}$ TA in $2015 ; 7,12,12.5$, and $9 \mathrm{~g} \cdot \mathrm{L}^{-1}$ TA in 2016. Total kilograms of fruit per vine and the number of clusters per vine were recorded and standardized to kilograms of fruit and cluster count per meter row for comparison among training systems. The cluster count per meter row was estimated by dividing the number of clusters per vine by the vine trellis length.

Grape cluster traits from individual vines were determined by weighing clusters and berries. The average berry weight was estimated from a subsample of 30 berries collected from six clusters within individual panels. The average cluster weight was estimated by dividing yield by total clusters per vine. Values for average number of berries per cluster were estimated by dividing the average cluster weight by mean berry weight. The cluster length was measured in a subsample of five clusters per vine (20 clusters per panel) from each four-vine panel treatment by measuring the distance of the cluster from the upper shoulder to the tail.

FrUIT SAMPLING. Forty-eight berries were randomly selected from 48 clusters across four-vine panel treatments on a weekly basis starting at veraison until harvest. Berries were selected considering location (right shoulder, left shoulder, center, and tail), cluster direction (facing toward or away from the canopy), and cluster position within the canopy (east or west side), with no specific pattern or rotation of selection points. Damaged berries were avoided during selection. Samples were collected in plastic bags and stored on ice for no more than $6 \mathrm{~h}$ until processed.
JUICE EXTRACTION AND FRUIT CHEMISTRY. Berries were pressed using a table-top aluminum hand juice press (WearEver; Alcoa, Richmond, VA) and filtered through a nylon mesh cloth to extract juice. The juice was decanted into plastic $50-\mathrm{mL}$ centrifuge tubes in volumes of $30 \mathrm{~mL}$ or greater. Juice sample SSC values were measured within $24 \mathrm{~h}$ of sampling by analyzing $0.5-\mathrm{mL}$ juice aliquots on a digital refractometer (model HI96801; Hanna Instruments, Woonsocket, RI). TA and $\mathrm{pH}$ values were determined using an automatic titration system (model HI902c; Hanna Instruments) with a fixed end-point method of $\mathrm{pH} 8.2$, 5 or $10 \mathrm{~mL}$ of sample, and $0.1 \mathrm{~N}$ sodium hydroxide titrant.

VINE VIgOR AND baLANCE. Dormant cane pruning weights were taken from 1-year-old canes of individual vines during spring dormant pruning for the 2015 and 2016 season of growth. Pruning weights were expressed as fresh biomass (kilograms) per meter row to standardize among treatments. The ratio of the weight of a season's yield to the cane biomass produced that season (taken as the pruning weights the following dormant season) is expressed as the Ravaz index [RI (Ravaz, 1911)]. The RI was used as an expression of crop load and was calculated as the ratio of fruit-to-cane production of a given year, for the years 2015 and 2016.

Canopy Density. Point quadrat analysis (PQA) was used to characterize leaf layer number (LLN), percent interior leaves (PIL), and percent interior clusters (PIC) along the fruiting zone $(10 \mathrm{~cm}$ below cordon for SHL and $\mathrm{HC}$, and $10 \mathrm{~cm}$ above cordon for SHU and VSP) for every panel treatment. In the $\mathrm{SH}$ training system, $\mathrm{SHU}$ and SHL were characterized separately. Data points for LLN, PIL, and PIC were measured by inserting a 0.5 $\mathrm{m}$-long by $6.5-\mathrm{mm}$-diameter rod into the fruiting zone, parallel to the ground level and perpendicular to the canopy, at $20-\mathrm{cm}$ intervals (Meyers and Vanden Heuvel, 2008). As the rod passed through the canopy fruiting zone, contact with leaves, clusters, and canopy gaps were recorded.

STATISTICAL ANALYSIS. Data were analyzed using a mixed linear model via the PROC MIXED procedure in SAS $^{\circledR}$ (version 9.4; SAS Institute, Inc., Cary, NC). Treatment and time were treated as fixed effects and block 
was treated as a random effect. Analysis of variance revealed a significant year by treatment interaction between 2015 and $2016(P \leq 0.05)$ for fruit yield parameters (i.e., kilograms of fruit, number of clusters, cluster length and weight, number of berries per cluster, and berry weight), so data were analyzed separately for each year. Fruit chemistry (i.e., SSC, TA, and $\mathrm{pH}$ ), dormant pruning weights, PQA parameters, and RI were analyzed using repeated measures with year as the time factor. Model assumptions of normality and constant variance were checked for all parameters using PROC GLM in SAS. If a significant treatment effect was detected $(P \leq 0.05)$, and treatment and time interaction was not significant in the repeated measures analysis, means were compared using Tukey's honestly significant difference at $\alpha=0.05$.

\section{Results}

Fruit yield and Cluster CHARACTERISTICS. In 2015, 'Brianna', 'Frontenac', and 'La Crescent' yields (kilograms of fruit per meter row) were higher in the $\mathrm{SH}$ system compared with VSP, and in 2016, all cultivars produced higher yields in $\mathrm{SH}$, followed by HC and VSP systems (Table 1). Yields in HC systems were also higher than those in VSP for 'La Crescent' in 2015. In 2015, the number of clusters per meter row was higher in the SH system for all cultivars, but not different from VSP in 'Brianna' or from HC in 'La Crescent'. In 2016, all cultivars produced more clusters in SH. Cluster weight (grams) was lower in the VSP system for 'Brianna' and 'La Crescent' in both years, although the difference was not always significant. Cluster weight was higher in vines trained in the HC system than in $\mathrm{SH}$ in 'Frontenac' and 'Marquette' in 2016 and 2015 , respectively. 'Marquette' clusters were longer in vines trained in $\mathrm{HC}$ systems than in VSP and $\mathrm{SH}$; similar results were observed for 'Frontenac' in 2015 (Table 1). 'La Crescent' clusters had a lower number of berries in both years in vines trained to the VSP system than $\mathrm{SH}$ $[P=0.008$ and 0.003 in 2015 and 2016, respectively (data not shown)]. There were no differences among treatments in berry weight for any of the cultivars evaluated $[P>0.05$ (data not shown)].

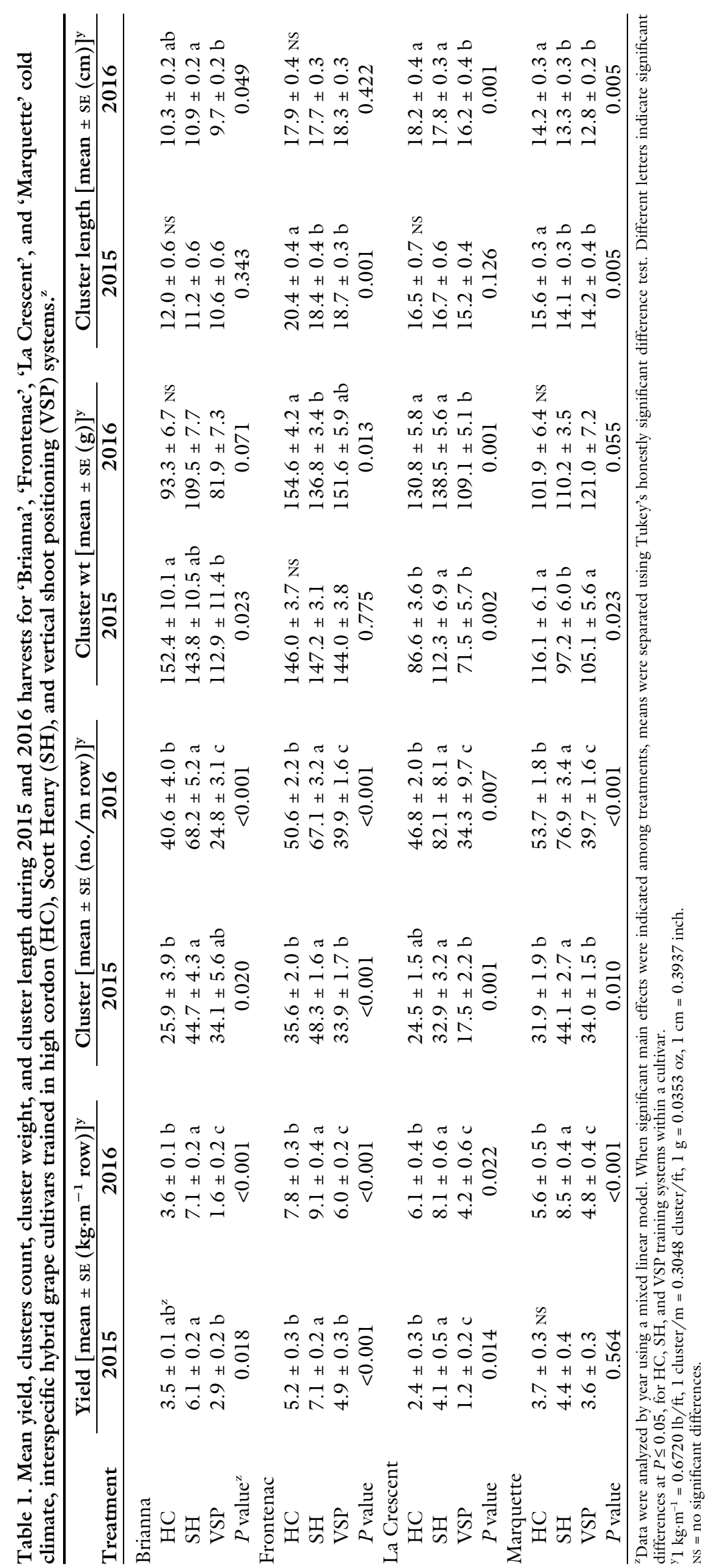


Fruit Chemistry. There were very few differences observed for fruit SSC, TA, and $\mathrm{pH}$ among the training systems during this 2-year study (Table 2). There were no differences for SSC among training systems for 'Brianna', 'Frontenac', or 'Marquette'; however, 'La Crescent' had higher SSC at harvest in vines trained to the HC system compared with VSP, but not different from those trained in SH. TA levels at harvest were similar among training systems, except for 'Frontenac' which had higher TA levels in HC compared with those in VSP (Table 2), but not different from $\mathrm{SH}$. Fruit $\mathrm{pH}$ at harvest in 'La Crescent' was higher in the SH system compared with that in VSP; however, no differences among treatments were observed for the other cultivars.
VINE SIZE AND BaLANCE. 'La Crescent' fresh dormant pruning biomass was higher in the $\mathrm{SH}$ training system than that in $\mathrm{HC}$ across the 2 -year study (Table 3 ), but not different from the VSP system. No differences in fresh dormant pruning weight were observed among training systems in the other cultivars evaluated. Vine balance, evaluated through the RI, was higher in the $\mathrm{SH}$ system compared with HC and VSP in 'Brianna', 'Frontenac', and 'La Crescent' (Table 3), but only different from VSP-trained vines in 'Marquette'. HC-trained vines had a higher RI than those trained in VSP in all cultivars evaluated.

Canopy Density. Training system significantly influenced canopy density over the 2 -year study period (Table 4). PQA results showed increased LLN in HC compared with
VSP and SHU in 'Brianna', 'Frontenac', and 'La Crescent', but no differences were observed in 'Marquette'. LLN values were not different between VSP and SHU and did not differ either between HC and SHL cordon in 'Frontenac' and 'La Crescent'. PIC was higher in HC compared with SHU in 'Brianna', 'Frontenac', and 'Marquette'; whereas PIL was also higher in HC for 'Brianna', 'Frontenac', and 'La Crescent'.

\section{Discussion}

Yield increases in divided canopy systems can be substantial (Bordelon et al., 2008; Reynolds et al., 1995; Zoecklein et al., 2008) as a result of retaining a higher number of nodes per vine and an increase in both budburst and fruitfulness or yield per node (Kliewer, 1982; Shaulis

Table 2. Mean soluble solids concentration (SSC), titratable acidity (TA), and pH of fruit at harvest during 2015 and 2016 for 'Brianna', 'Frontenac', 'La Crescent', and 'Marquette' cold climate, interspecific hybrid grape cultivars trained in high cordon (HC), Scott Henry (SH), and vertical shoot positioning (VSP) systems. ${ }^{\mathrm{z}}$

\begin{tabular}{|c|c|c|c|c|c|c|c|c|c|}
\hline \multirow[b]{3}{*}{ Treatment } & \multicolumn{3}{|c|}{$\operatorname{SSC}[$ mean \pm SE $(\%)]$} & \multicolumn{3}{|c|}{$\mathrm{TA}\left[\text { mean } \pm \mathrm{SE}\left(\mathrm{g} \cdot \mathrm{L}^{-1}\right)\right]^{\mathrm{y}}$} & \multicolumn{3}{|c|}{$\mathrm{pH}($ mean $\pm \mathrm{SE})$} \\
\hline & & & Tukey's & & & Tukey's & & & Tukey's \\
\hline & 2015 & 2016 & HSD $^{\mathrm{z}}$ & 2015 & 2016 & HSD & 2015 & 2016 & HSD \\
\hline $\mathrm{HC}$ & $19.4 \pm 0.4$ & $16.5 \pm 0.8$ & NS & $6.1 \pm 0.2$ & $7.2 \pm 0.2$ & NS & $3.42 \pm 0.03$ & $3.26 \pm 0.02$ & NS \\
\hline $\mathrm{SH}$ & $17.6 \pm 0.4$ & $16.0 \pm 0.3$ & & $5.7 \pm 0.3$ & $6.9 \pm 0.3$ & & $3.43 \pm 0.02$ & $3.23 \pm 0.03$ & \\
\hline VSP & $19.1 \pm 0.4$ & $16.8 \pm 0.3$ & & $5.3 \pm 0.5$ & $7.1 \pm 0.4$ & & $3.46 \pm 0.02$ & $3.25 \pm 0.04$ & \\
\hline Treatment $\times$ year & & & 0.415 & & & 0.470 & & & 0.674 \\
\hline \multicolumn{10}{|l|}{ Frontenac } \\
\hline $\mathrm{HC}$ & $23.0 \pm 0.5$ & $21.2 \pm 0.6$ & NS & $13.0 \pm 0.5$ & $13.0 \pm 0.2$ & a & $3.36 \pm 0.02$ & $3.41 \pm 0.01$ & NS \\
\hline $\mathrm{SH}$ & $23.8 \pm 0.2$ & $22.1 \pm 0.3$ & & $12.7 \pm 0.4$ & $11.9 \pm 0.1$ & $\mathrm{ab}$ & $3.35 \pm 0.02$ & $3.44 \pm 0.01$ & \\
\hline VSP & $23.3 \pm 0.5$ & $21.8 \pm 0.3$ & & $12.0 \pm 0.2$ & $12.2 \pm 0.2$ & $\mathrm{~b}$ & $3.38 \pm 0.04$ & $3.46 \pm 0.01$ & \\
\hline \multicolumn{10}{|l|}{$P$ value } \\
\hline $\mathrm{HC}$ & $20.9 \pm 0.5$ & $19.3 \pm 0.3$ & $\mathrm{a}$ & $12.2 \pm 0.3$ & $14.2 \pm 1.1$ & NS & $3.08 \pm 0.02$ & $3.21 \pm 0.01$ & $a b$ \\
\hline $\mathrm{SH}$ & $19.6 \pm 0.0$ & $18.8 \pm 0.4$ & $a b$ & $11.6 \pm 0.4$ & $12.3 \pm 0.2$ & & $3.14 \pm 0.04$ & $3.22 \pm 0.00$ & $\mathrm{a}$ \\
\hline VSP & $18.5 \pm 0.2$ & $19.1 \pm 0.4$ & $\mathrm{~b}$ & $12.9 \pm 0.8$ & $13.1 \pm 0.3$ & & $3.04 \pm 0.03$ & $3.21 \pm 0.01$ & $\mathrm{~b}$ \\
\hline \multicolumn{10}{|l|}{$P$ value } \\
\hline Treatment & & & 0.006 & & & 0.108 & & & 0.040 \\
\hline Treatment $\times$ year & & & 0.210 & & & 0.436 & & & 0.065 \\
\hline \multicolumn{10}{|l|}{ Marquette } \\
\hline $\mathrm{HC}$ & $24.6 \pm 0.1$ & $23.2 \pm 0.4$ & NS & $8.8 \pm 0.1$ & $11.0 \pm 0.8$ & NS & $3.43 \pm 0.02$ & $3.22 \pm 0.01$ & NS \\
\hline $\mathrm{SH}$ & $24.5 \pm 0.4$ & $22.7 \pm 0.6$ & & $8.7 \pm 0.3$ & $9.9 \pm 0.3$ & & $3.40 \pm 0.01$ & $3.26 \pm 0.03$ & \\
\hline VSP & $24.3 \pm 0.3$ & $24.1 \pm 0.3$ & & $8.3 \pm 0.1$ & $10.4 \pm 0.2$ & & $3.47 \pm 0.02$ & $3.29 \pm 0.02$ & \\
\hline \multicolumn{10}{|l|}{$P$ value } \\
\hline Treatment & & & 0.224 & & & 0.153 & & & 0.054 \\
\hline
\end{tabular}


Table 3. Mean dormant cane pruning for biomass produced during 2015 and 2016 and Ravaz index (RI) values for 2015 and 2016 for 'Brianna', 'Frontenac', 'La Crescent', and 'Marquette' cold climate, interspecific hybrid grape cultivars trained in high cordon (HC), Scott Henry (SH), and vertical shoot positioning (VSP) systems. ${ }^{\mathrm{z}}$

\begin{tabular}{|c|c|c|c|c|c|c|}
\hline \multirow[b]{2}{*}{ Treatment } & \multicolumn{3}{|c|}{ Dormant cane pruning wt $\left[\text { mean } \pm \mathrm{SE}\left(\mathrm{kg} \cdot \mathrm{m}^{-1} \text { row }\right)\right]^{\mathrm{y}}$} & \multicolumn{3}{|c|}{$\mathrm{RI}\left[\right.$ mean $\left.\pm \mathrm{SE}\left(\mathrm{kg} \cdot \mathrm{kg}^{-1}\right)\right]$} \\
\hline & 2015 & 2016 & Tukey's HSD $^{\mathrm{z}}$ & 2015 & 2016 & Tukey's HSD \\
\hline \multicolumn{7}{|l|}{ Brianna } \\
\hline $\mathrm{SH}$ & $0.97 \pm 0.24$ & $1.58 \pm 0.19$ & & $12.10 \pm 1.42$ & $5.37 \pm 0.73$ & $\mathrm{a}$ \\
\hline VSP & $1.14 \pm 0.09$ & $1.90 \pm 0.24$ & & $4.90 \pm 1.19$ & $1.17 \pm 0.19$ & $\mathrm{c}$ \\
\hline \multicolumn{7}{|l|}{$P$ value ${ }^{\mathrm{z}}$} \\
\hline \multicolumn{7}{|l|}{ Frontenac } \\
\hline $\mathrm{HC}$ & $1.40 \pm 0.09$ & $1.42 \pm 0.13$ & NS & $8.84 \pm 0.83$ & $9.35 \pm 0.76$ & $\mathrm{~b}$ \\
\hline $\mathrm{SH}$ & $1.17 \pm 0.08$ & $1.41 \pm 0.14$ & & $12.38 \pm 0.92$ & $10.13 \pm 0.77$ & $\mathrm{a}$ \\
\hline VSP & $1.10 \pm 0.08$ & $1.59 \pm 0.13$ & & $7.83 \pm 0.98$ & $6.52 \pm 0.47$ & c \\
\hline \multicolumn{7}{|l|}{$P$ value } \\
\hline $\mathrm{SH}$ & $1.65 \pm 0.14$ & $2.91 \pm 0.49$ & $\mathrm{a}$ & $3.34 \pm 0.52$ & $7.00 \pm 1.21$ & $\mathrm{a}$ \\
\hline VSP & $1.50 \pm 0.09$ & $2.57 \pm 0.14$ & $\mathrm{ab}$ & $0.97 \pm 0.14$ & $4.12 \pm 1.52$ & $\mathrm{~b}$ \\
\hline \multicolumn{7}{|l|}{$P$ value } \\
\hline Treatment & & & 0.010 & & & $<0.001$ \\
\hline Treatment $\times$ year & & & 0.801 & & & 0.321 \\
\hline \multicolumn{7}{|l|}{ Marquette } \\
\hline $\mathrm{HC}$ & $1.65 \pm 0.15$ & $2.07 \pm 0.17$ & NS & $4.56 \pm 0.61$ & $6.85 \pm 1.37$ & $\mathrm{a}$ \\
\hline $\mathrm{SH}$ & $1.36 \pm 0.12$ & $2.26 \pm 0.22$ & & $4.82 \pm 0.68$ & $7.19 \pm 0.79$ & $\mathrm{a}$ \\
\hline VSP & $1.34 \pm 0.07$ & $2.31 \pm 0.15$ & & $3.53 \pm 0.27$ & $3.25 \pm 0.26$ & $\mathrm{~b}$ \\
\hline \multicolumn{7}{|l|}{$P$ value } \\
\hline Treatment & & & 0.683 & & & 0.028 \\
\hline
\end{tabular}

et al., 1966; Smart et al., 1990). In this study, canopy division had a significant effect on yield with vines in the $\mathrm{SH}$ system, producing higher yields (kilograms of fruit per meter row) than those trained in $\mathrm{HC}$ and VSP for all cultivars, even when vines in the $\mathrm{SH}$ system were thinned to remove $25 \%$ of cluster to avoid overcropping of the young vines. The increase in yield observed in the $\mathrm{SH}$ system was mainly a result of increased number of shoots per vine, as vines trained in the $\mathrm{SH}$ system had twice the cordon length, resulting in a higher number of shoots per linear length of canopy. Increases in productivity of divided canopy systems have also been attributed to a higher number of shoots growing from base buds, referred to as noncount shoots (Kliewer and Smart, 1989; May et al., 1973). This may have contributed to the higher yields observed in the $\mathrm{SH}$ system; however, we did not evaluate the number of shoots produced from basal buds.

Less expected was the yield difference observed between vines trained in HC and VSP systems, particularly in 2016, as both systems had similar cordon lengths, and shoot density was adjusted in each to 20 shoots $/ \mathrm{m}$ of cordon. Increased yield in vines trained in HC system compared with those trained in VSP was observed in both years in 'La Crescent' and in at least one of the years for the other three cultivars. It is possible that differences between these two training systems were not as evident in 2015 , the first year of the study, because vines were still being trained, as well as it being their first cropping year. Similar differences were observed in the number of clusters between VSP and HC in 2016, but not for cluster weights (Table 1), which suggests that differences in yield between VSP- and HC-trained vines might have been driven by differences in the number of clusters produced by shoots. Shoots arising from base (noncount) and proximal (count) buds, as well as shoots produced from primary, secondary, and tertiary buds, differ in their level of fruitfulness (Pool et al., 1978; Sánchez and Dokoozlian, 2005) and thus can affect productivity even when the number of shoots per cordon length is standardized. The number of nodes retained per spur after pruning may also affect the yield, as node fruitfulness varies depending on the node position in the cane (Khanduja and Balasubrahmanyam, 1972; May 2004). Studies in American cultivars have reported low productivity of buds located in lower positions in canes (Pool et al., 1978; Swartwout, 1925), which is one of the reasons 
Table 4. Point quadrat analysis means for leaf layer numbers (LLN), percent interior clusters (PIC), and percent interior leaves (PIL) during 2015 and 2016 for 'Brianna', 'Frontenac', 'La Crescent', and 'Marquette' cold climate, interspecific hybrid grape cultivars trained in high cordon $(\mathrm{HC})$, Scott Henry [ $\mathrm{SH}(\mathrm{SHL}=\mathrm{SH}$ lower cordon; SHU = SH upper cordon $)]$, and vertical shoot positioning (VSP) systems. ${ }^{\mathrm{z}}$

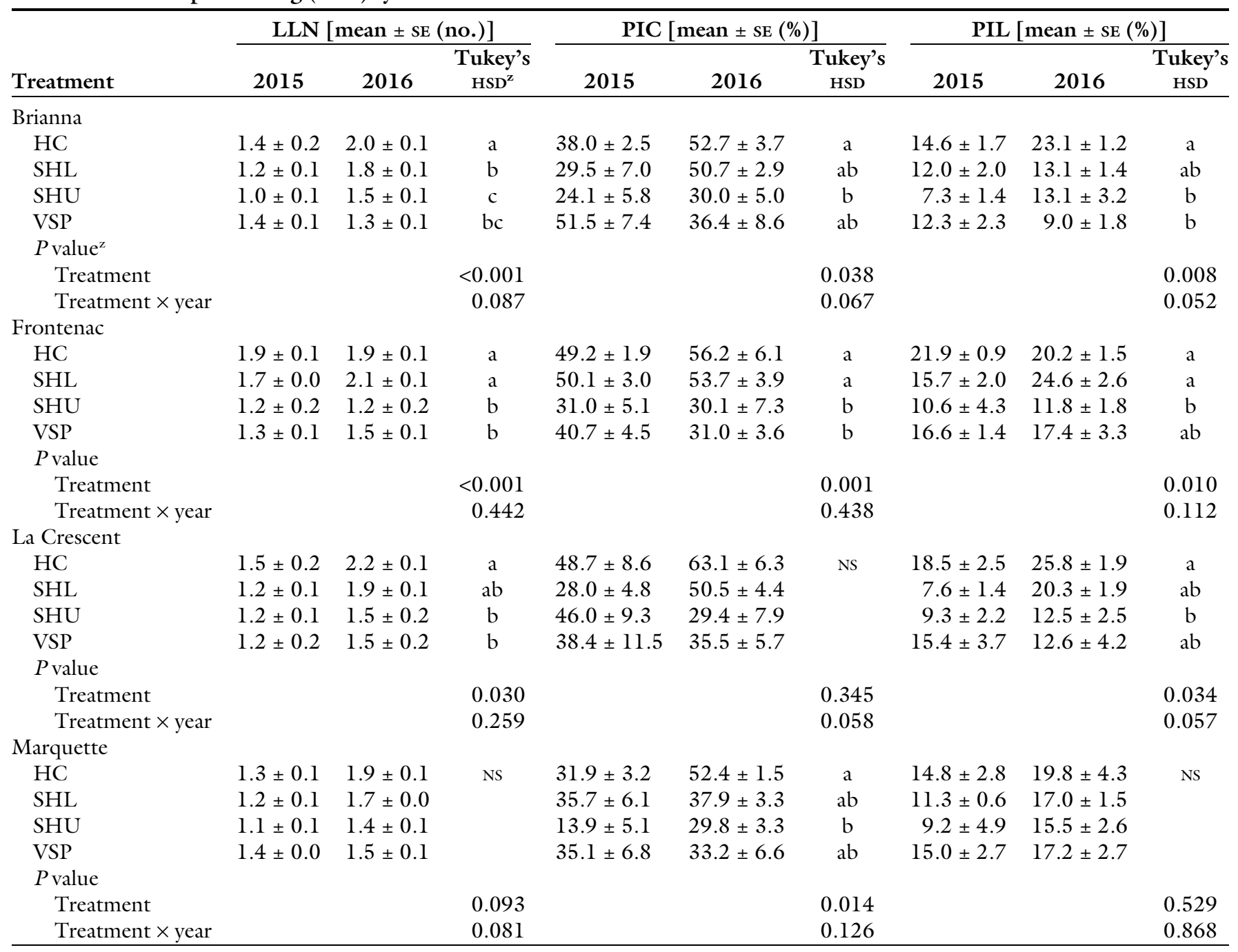

${ }^{\mathrm{z} D a t a}$ were analyzed using a repeated measurement model, accounting for the overall effect of treatments throughout the 2 -year study. When significant main effects were indicated among treatments, means were separated using Tukey's HSD test. Different letters indicate significant differences at $P \leq 0.05$, for HC, SH, and VSP training systems within a cultivar.

$\mathrm{NS}=$ no significant differences; HSD $=$ honestly significant difference.

'Concord' grapes are pruned to six buds per spur when trained in $\mathrm{HC}$ training system (Martinson et al., 2012). In our study, vines trained in the VSP system were pruned to two nodes per spur, whereas those in HC were pruned to four nodes per spur. Although there is no information on fruitfulness as related to the node position in CCIHG cultivars, it is possible that differences in yield between treatments could be at least partially explained by differences in fruitfulness of nodes based on position. In addition, downward positioning of shoots in $\mathrm{HC}$ allows more sunlight to penetrate the canopy and increase light and temperature of developing buds, and thus node fruitfulness. Studies on canopy management have shown that temperature and the amount of light affect the number of shoots per node, the number of inflorescences per shoot, and the size of the inflorescence primordium (Dry, 2000; May et al., 1976; Sánchez and Dokoozlian, 2005; Sommer et al., 2000). Training system studies in CCIHG cultivars have reported higher midday sunlight levels in the fruit zone and higher yields per node in $\mathrm{HC}$ canopies compared with VSP (Bavougian et al., 2012,2013 ), as well as higher yields per shoot (Luby, 2012; Martinson et al., 2015).

Downward shoot positioning in grapes can reduce vine vigor, by reducing the growth rate of shoots, the length of internodes, and total shoot growth (Kliewer et al., 1989; Smart et al., 1982b). Growth reduction of shoots in the downward position results from smaller xylem vessel formation in the secondary xylem, possibly because of an increase in auxin concentration at the apex and the proximal shoot portions (Lovisolo et al., 2002). This consequently reduces sap flow and decreases hydraulic conductivity and stomatal conductance to leaves (Schubert et al., 1999). In this study, dormant cane pruning biomass was used as a measure of vine vigor, and differences among training systems were minimal, except for 'La Crescent', 
which was the only cultivar to show differences in yield among all training systems during both years of the study. Dormant cane pruning weight may not be a fully accurate indicator of vine growth, as distal vegetative growth was controlled by hedging and skirting. This may have obscured differences in vine vegetative growth among training systems. In fact, vines in the VSP system needed twice as much vegetative growth control than those in $\mathrm{HC}$ and $\mathrm{SH}$. In addition, VSP vines required extra leaf removal to expose clusters during the ripening period. Because dormant pruning weights did not reflect accurately the vines' vegetative growth, results from the RI are mostly driven by the yield differences among training systems. It is noteworthy that the VSP RI values for most of the cultivars were below the European and American wine grape cultivar ideal range of 5-10 and $8-11$, respectively (Howell, 2001; Kliewer and Dokoozlian, 2005). The low RI values reflect that vines were undercropped in the VSP system, and likely in the HC system as well, a factor which would further promote vegetative growth.

Several studies in European and hybrid wine grape cultivars have shown a decrease in canopy density in training systems with downward shoot positioning, as a result of a reduction in vigor (Bavougian et al., 2012; Vanden Heuvel et al., 2004). However, the results in our study show the opposite trend (Table 4), with most cultivars showing increased LLN, PIC, and PIL in the HC and SHL compared with VSP and SHU. Shoots of vines in VSP and SHU were periodically positioned between catch wires on the trellis, by contrast to $\mathrm{HC}$ shoots that were left unpositioned and consequentially grew in a more disorderly manner throughout the fruiting zone. Thus, it is possible that the less organized shoot growth might have led to an increase in shoot overlapping, resulting in an increase in the LLN in the fruit zone of cordons with downwardpositioned shoots. It is noteworthy that there is a strong negative correlation between LLN and PAR in the fruiting zone for VSP systems, but this correlation is weaker for non-VSP systems (Gladstone and Dokoozlian, 2003; Vanden Heuvel et al., 2004), implying that higher LLN in HC and SHL does not necessarily reflect less light interception in the fruiting zone.
In fact, with respect to fruit SSC and TA, there were very few differences among the training systems in our study, despite the differences in yield. This supports the hypothesis that higher canopy density in systems with downward shoot positioning does not necessarily translate into lower light interception in the fruit zone.

Similar to results reported in previous studies (Bordelon et al., 2008; Howell et al., 1987; Vanden Heuvel et al., 2013; Wolpert et al., 1983), we observed minimal differences in fruit chemistry parameters between the nondivided canopy systems VSP and $\mathrm{HC}$, despite the differences in yield. However, our results differ from those in the literature in that we did not observe differences in fruit chemistry between the divided canopy system $\mathrm{SH}$ and the nondivided systems $\mathrm{HC}$ and VSP, which is usually attributed to an improved light interception in divided canopy systems (Reynolds and Vanden Heuvel, 2009; Smart et al., 1985). Throughout the study, canopy management in all three training systems aimed at applying commercial production practices to improve fruit composition in cold climate regions. Basal leaf and lateral shoot removal were imposed in all systems and cultivars, which likely enhanced the effects of sunlight and temperature in the fruit zone inherent to each of the training systems, and thus the effects on fruit chemistry. These results also suggest that CCIHG cultivars have the capacity to sustain higher crop sizes than the ones achieved with the traditional VSP system, without having a detrimental effect on fruit chemistry. Similar results have been observed in divided canopy experiments where despite increases in yield components, no effects were observed in fruit chemistry (May et al., 1973; Shaulis and May, 1971). Even though vines trained in divided canopy systems, such as $\mathrm{SH}$, produce significantly higher yields than those in VSP and HC, crop load levels for vines in our $\mathrm{SH}$ system were still in the recommended range for European and American wine grapes, implying that vines were not crop stressed, and thus no reduction in fruit quality was observed for this treatment.

\section{Conclusions}

This study evaluated the impact of training systems on yield, fruit composition, vine size and balance, and canopy density for conventionally managed CCIHG cultivars Brianna, Frontenac, La Crescent, and Marquette. The divided canopy training system $\mathrm{SH}$ increased the crop yield per meter of row in all cultivars relative to $\mathrm{HC}$ and VSP, even though a $25 \%$ reduction in crop size was imposed on these vines. Vines trained to VSP had lower yields compared with HC, and this was most evident during the second year of the study, as vines were still being trained when the study began. Despite the higher crop load associated with vines trained in the $\mathrm{SH}$ system, there were minimal differences in fruit SSC, TA, and $\mathrm{pH}$ at harvest time, suggesting that CCIHG cultivars were undercropped in VSP and HC systems. Therefore, these hybrids may have the capacity to support higher fruit yields without compromising fruit composition traits. Differences in vine size, expressed as dormant cane weight, were obscured by hedging and skirting of shoots during the growing season to control vegetative vigor; vines in the VSP system required intensive management to ensure a well-exposed fruit zone. Although not evaluated in this study, the labor requirement involved in training vines to more complex training systems, such as $\mathrm{SH}$, must be considered when choosing a training system for CCIHG cultivars.

\section{Literature cited}

Atucha, A., J. Hedtcke, and B.A. Workmaster. 2018. Evaluation of coldclimate interspecific hybrid wine grape cultivars for the upper midwest. J. Amer. Pomol. Soc. (In press).

Bavougian, C.M., P.E. Read, V.L. Schlegel, and K.J. Hanford. 2013. Canopy light effects in multiple training systems on yield, soluble solids, acidity, phenol and flavonoid concentration of 'Frontenac' grapes. HortTechnology 23:86-92.

Bavougian, C.M., P.E. Read, and E. Walter-Shea. 2012. Training system effects on sunlight penetration, canopy structure, yield, and fruit characteristics of 'Frontenac' grapevine (Vitis spp.). Intl. J. Fruit Sci. 12:402-409.

Bordelon, B., R. Foster, and N.W. Gautier (eds.). 2015. Midwest small fruit and grape spray guide. Purdue Univ. ID-169.

Bordelon, B.P., P.A. Skinkis, and P.H. Howard. 2008. Impact of training system on vine performance and fruit composition of 'Traminette'. Amer. J. Enol. Viticult. 59:39-46. 
Dami, I., B. Bordelon, D.C. Ferree, M. Brown, M.A. Ellis, R.N. Williams, and D. Doohan. 2005. Midwest grape production guide. Ohio State Univ. Ext. Bul. 919.

Dokoozlian, N.K. and W.M. Kliewer. 1995. The light environment within grapevine canopies. I. Description and seasonal changes during fruit development. Amer. J. Enol. Viticult. 46:209-218.

Dry, P.R. 2000. Canopy management for fruitfulness. Austral. J. Grape Wine Res. 6:109-115.

Gladstone, E.A. and N.K. Dokoozlian. 2003. Influence of leaf area density and trellis/training system on the light microclimate within grapevine canopies. Vitis 42:123-131.

Hemstad, P.R. and J.J. Luby. 2000. Utilization of Vitis riparia for the development of new wine varieties with resistance to disease and extreme cold. Acta Hort. 528:487-496.

Howell, G.S. 2001. Sustainable grape productivity and the growth-yield relationship: A review. Amer. J. Enol. Viticult. 52:165-174.

Howell, G.S., T.K. Mansfield, and J.A. Wolpert. 1987. Influence of training system, pruning severity, and thinning on yield, vine size, and fruit quality of 'Vidal Blanc' grapevines. Amer. J. Enol. Viticult. 38:105-112.

Howell, G.S., D.P. Miller, C.E. Edson, and R.K. Striegler. 1991. Influence of training system and pruning severity on yield, vine size, and fruit composition of 'Vignoles' grapevines. Amer. J. Enol. Viticult. 42:191-198.

Katerji, N., F. Daudet, A. Carbonneau, and N. Ollat. 1994. Etude à l'échelle de la plante entière du fonctionnement hydrique et photosynthétique de la vigne: Comparaison des systèmes de conduite traditionnel et en Lyre. Vitis 33:197-203.

Khanduja, S.D. and V.R. Balasubrahmanyam. 1972. Fruitfulness of grape vine buds. Econ. Bot. 26:280-294.

Kliewer, W.M. 1982. Vineyard canopy management: A review. Grape Wine Centennial Proc. 1:342-352.

Kliewer, W.M., P. Bowen, and M. Benz. 1989. Influence of shoot orientation on growth and yield development in 'Cabernet Sauvignon'. Amer. J. Enol. Viticult. 40:259-264.

Kliewer, W.M. and N.K. Dokoozlian. 2005. Leaf area/crop weight ratios of grapevines: Influence on fruit composition and wine quality. Amer. J. Enol. Viticult. 56:170-181.
Kliewer, W.M. and R.E. Smart. 1989. Canopy manipulation for optimizing vine microclimate, crop yield and composition of grapes, p. 275-291. In: C.J. Wright (ed.). Manipulation of fruiting. Butterworth, London, UK.

Lovisolo, C., A. Schubert, and C. Sorce. 2002. Are xylem radial development and hydraulic conductivity in downwardlygrowing grapevine shoots influenced by perturbed auxin metabolism? New Phytol. 156:65-74.

Luby, C. 2012. The effect of training system and yield on fruit quality of 'Marquette' and 'La Crescent' wine grapes (Vitis spp.) in a Vermont vineyard. J. Amer. Pomol. Soc. 66:34-38.

Martinson, T., A. Lakso, and T. Bates. 2012. Bud fruitfulness and yield. $20 \mathrm{Mar}$. 2018. <https://grapesandwine.cals. cornell.edu/newsletters/appellationcornell/2012-newsletters/issue-10/ bud-fruitfulness-and-yield/>.

Martinson, T., J. Thull, and B. Utter. 2015. Comparing and contrasting vertical shoot positioning and top wire cordon training systems. 22 Jan. 2018. <http:// northerngrapesproject.org/wp-content/ uploads/2015/02/VSPandTWCwebinar.pdf $/>$.

May, P. 2004. Flowering and fruitset in grapevines. Lythrum Press, Adelaide, Australia.

May, P., P.R. Clingeleffer, and C.J. Brien. 1976. Sultana (Vitis vinifera L.) canes and their exposure to light. Vitis 14:278-288.

May, P., M.R. Sauer, and P.B. Scholefield. 1973. Effect of various combinations of trellis, pruning and rootstock on vigorous Sultana vines. Vitis 12:192-206.

Meyers, J.M. and J.E. Vanden Heuvel. 2008. Enhancing the precision and spatial acuity of point quadrat analyses via calibrated exposure mapping. Amer. J. Enol. Viticult. 59:425-431.

National Oceanographic and Atmospheric Administration. 2017. cli-MATE Midwest Regional Climate Center. 20 Mar. 2018. <http://mrcc.isws.illinois. edu/CLIMATE/>.

Pereira, G., J.P. Gaudillere, P. Pieri, G. Hilbert, M. Maucourt, C. Deborde, A. Moing, and D. Rolin. 2006. Microclimate influence on mineral and metabolic profiles of grape berries. J. Agr. Food Chem. 54:6765-6775.

Pool, R.M., C. Pratt, and H.D. Hubbard. 1978. Structure of base buds in relation to yield of grapes. Amer. J. Enol. Viticult. 29:36-41.

Ravaz, M.L. 1911. L'effeuillage de la vigne. Annales de l'Ecole Nationale
d'Agriculture de Montpellier 11:216244.

Reynolds, A.G. and J.E. Vanden Heuvel. 2009. Influence of grapevine training systems on vine growth and fruit composition: A review. Amer. J. Enol. Viticult. 60:251-268.

Reynolds, A.G. and D.A. Wardle. 1994. Impact of training system and vine spacing on vine performance and berry composition of Seyval blanc. Amer. J. Enol. Viticult. 45:444-451.

Reynolds, A.G., D.A. Wardle, M.A. Cliff, and M. King. 2004. Impact of training system and vine spacing on vine performance, berry composition, and wine sensory attributes of Seyval and Chancellor. Amer. J. Enol. Viticult. 55:84-95.

Reynolds, A.G., D.A. Wardle, and A.P. Naylor. 1995. Impact of training system and vine spacing on vine performance and berry composition of Chancellor. Amer. J. Enol. Viticult. 46:88-97.

Sánchez, L.A. and N.K. Dokoozlian. 2005. Bud microclimate and fruitfulness in Vitis vinifera L. Amer. J. Enol. Viticult. 56:319-329.

Schubert, A., C. Lovisolo, and E. Peterlunger. 1999. Shoot orientation affects vessel size, shoot hydraulic conductivity and shoot growth rate in Vitis vinifera L. Plant Cell Environ. 22:197-204.

Schultz, H. 1995. Grape canopy structure, light microclimate and photosynthesis. I. A two-dimensional model of the spatial distribution of surface area densities and leaf ages in two canopy systems. Vitis 34:211-215.

Shaulis, N.J., H. Amberg, and D. Crowe. 1966. Response of Concord grapes to light, exposure and Geneva double curtain training. Proc. Amer. Soc. Hort. Sci. 89:268-280.

Shaulis, N.J. and P. May. 1971. Response of 'Sultana' vines to training on a divided canopy and to shoot crowding. Amer. J. Enol. Viticult. 22:215-222.

Smart, R. and M. Robinson. 1991. Sunlight into wine: A handbook for winegrape canopy management. Winetitles, Adelaide, Australia.

Smart, R.E., J.K. Dick, I.M. Gravett, and B.M. Fisher. 1990. Canopy management to improve grape yield and qualityPrinciples and practices. S. Afr. J. Enol. Viticult. 11:3-17.

Smart, R.E., J.B. Robinson, G.R. Due, and C.J. Brien. 1985. Canopy microclimate modification for the cultivar Shiraz II. Effects on must and wine composition. Vitis 24:119-128. 
Smart, R.E., N.J. Shaulis, and E.R. Lemon. 1982a. The effect of concord vineyard microclimate on yield. I. The effects of pruning, training, and shoot positioning on radiation microclimate. Amer. J. Enol. Viticult. 33:99-108.

Smart, R.E., N.J. Shaulis, and E.R. Lemon. 1982b. The effect of concord vineyard microclimate on yield. II. The interrelations between microclimate and yield expression. Amer. J. Enol. Viticult. 33:109-116.

Sommer, K.J., M.T. Islam, and P.R. Clingeleffer. 2000. Light and temperature effects on shoot fruitfulness in Vitis vinifera L. cv. Sultana: Influence of trellis type and grafting. Austral. J. Grape Wine Res. 6:99-108.

Swartwout, H. 1925. Fruit habit of the grape. Proc. Amer. Soc. Hort. Sci. 22:70-72.

U.S. Department of Agriculture. 2012. Plant hardiness zone map. 20 Mar. 2018. $<$ http://planthardiness.ars.usda.gov/>.
U.S. Department of Agriculture. 2017. Web soil survey. 20 Mar. 2018. <http:// websoilsurvey.sc.egov.usda.gov/App/ HomePage.htm/>.

Vanden Heuvel, J.E., S. Lerch, C. Coquard Lenerz, J.R. Meyer, and A.K. Mansfield. 2013. Training system and vine spacing impact vine growth, yield, and fruit composition in a vigorous young 'Noiret' vineyard. HortTechnology 23:505-510.

Vanden Heuvel, J.E., J.T.A. Proctor, J.A. Sullivan, and K.H. Fisher. 2004. Influence of training/trellising system and rootstock selection on productivity and fruit composition of Chardonnay and Cabernet franc grapevines in Ontario, Canada. Amer. J. Enol. Viticult. 55:253-264.

Vasconcelos, M.C., M. Greven, C.S. Winefield, M.C.T. Trought, and V. Raw. 2009. The flowering process of Vitis vinifera: A review. Amer. J. Enol. Viticult. 60:411-434.
Wolf, T.K. (ed.). 2008. Wine grape production guide for eastern North America. Natural Resources Agr. Eng. Serv. \#145.

Wolpert, J.A., G.S. Howell, and T.K. Mansfield. 1983. Sampling Vidal blanc grapes. I. Effect of training system, pruning severity, shoot exposure, shoot origin, and cluster thinning on cluster weight and fruit quality. Amer. J. Enol. Viticult. 34:72-76.

Zoecklein, B.W., T.K. Wolf, L. Pélanne, M.K. Miller, and S.S. Birkenmaier. 2008. Effect of vertical shoot-positioned, SmartDyson, and Geneva double-curtain training systems on Viognier grape and wine composition. Amer. J. Enol. Viticult. 59:11-21. 